\title{
PSYCHOLOGICAL AND PEDAGOGICAL FEATURES OF TEENAGERS IN THE CONTEXT OF AESTHETIC EDUCATION
}

\author{
Larisa Sierykh \\ Candidate of Pedagogical Sciences, Associate Professor, Senior Lecturer at the Department \\ of Theory and Methods of Educational Content, \\ Sumy Regional Institute of Postgraduate Pedagogical Education, Ukraine \\ e-mail: Su181260slv@ukr.net, orcid.org/0000-0001-5290-8596
}

Agnieszka Kamtoh

MA, Polonia University in Czestochowa, Interdisciplinary Faculty, Poland e-mail: akamtoh@ap.edu.pl,orcid.org/0000-0002-3930-8278

\section{Summary}

The aim of this paper is to prove: to determine the main periods of individual mental development of the individual and their criteria, which include characteristic for each age social situation of development, leading activities in its relationship with other activities. In our study - this is an aesthetic activity provided by effective aesthetic education of adolescents. The mental development of the body of adolescents occurs within a certain function of the psyche and is based on the mechanisms of maturation of the relevant physiological systems. This suggests that teenager is a transition between childhood and adulthood and it determines the uniqueness of the social situation of its development. In adolescence, there is a change in reference orientations. As a «significant teenager», he is looking for a reference group - a real or conditional community in which he can carry out acts of self-affirmation. There is a need for self-improvement, self-esteem, the need to «understand yourself». The teenager motives become more conscious, more fully and deeply experienced. The socialization occurs without any problems. We create a situation of acme success, which under the conditions of effective aesthetic activity provides aesthetic education of teenagers. The teenagers, performing any aesthetic activity and receiving certain information, socialize; develop in various ways and harmoniously.

Keywords: mental development of teenagers, out-of-school education, general secondary education, interaction of educational institutions, aesthetic education.

DOI: https://doi.org/10.23856/4022

\section{Introduction}

The relevance of the article lies in the daily encouragement of teenagers to aesthetic activities, as it harmonizes the personality, allows of teenagers to reveal their own talents, preferences, interests. Solving the problem of psychological characteristics of teenagers is important in aesthetic education, because it is the formation and development of personal self-awareness.

The aim of the article is: to show the psycho-physiological features of teenagers in the context of aesthetic education. The main periods of individual mental development of the individual, tasks - to characterize; determine the dependence of psychological characteristics of teenagers in aesthetic education; identify opportunities for aesthetic education of teenagers; forms of aesthetic activity of teenagers. 


\section{The main periods of individual mental development of the individual}

The importance of psychological and pedagogical features of teenagers as subjects of interaction in aesthetic education was emphasized by psychologists B. B. Ananiev, 1977; 1980; I. Bekh, 2003; 2003a; 2012; 1998; L. Vyhotskyi, 2001; M. Zabrodskyi, 1998; H. Kondratenko, 2003; H. Kostiuk, 2005; O. Leontiev, 1985; P. Miasoid, 2001; B. Teplov, 2001; L. Terletska, 2013 and others.

Thus, L. Terletska notes that the real criteria for determining the main periods of individual mental development of the individual should be «qualitative features, not external, but significant, taken not separately from each other, but in their systemic connection, which reveals specific to each age stage of integral neoplasms. Such are the mental and social changes in a person's life, which determine his consciousness and activity, his attitude to the environment, the whole course of his development at this stage» (Terletska, 2013).

The periods defining of development of mental activity, G. Kostiuk takes into account all its aspects in the unity of content, operation and motivation and emphasizes the importance of understanding the relationship between periods and stages of mental development, the dynamics of transition from previous to subsequent stages (Kostiuk, 2005).

Based on the results of scientific research L. Terletska, we can say that the definition of psychological development of teenagers as a subject of pedagogical interaction is based on psychological criteria, which include the age-specific social situation of development, leading activities in its relationship with other activities, including aesthetic, neoplasm of age, the appropriate level of development of consciousness and self-awareness of the individual (Terletska, 2013: 13).

Physiological features of the teenagers as a subject of pedagogical interaction characterize the mechanisms of psycho \& physiological systems that perform an instrumental function. According to P. Miasoid, this gives grounds to judge the age dynamics of one of the leading characteristics of the electroencephalogram - the alpha rhythm of a person, which "passes an unstable phase" in adolescence (Miasoid, 2001: 140).

In addition, the physiological \& psychological specificity of the development of spiritual principles in teenagers is determined by the processes of acceleration. During this period, the body grows rapidly; there is an intensive formation of the cardiovascular and nervous systems, endocrine glands, puberty. This is a critical period in the maturation of morphological systems of the organism, during which their actual restructuring takes place. It is no coincidence that he is the one who suffers from physical disorders.

P. Miasoid research shows that mental development at the level of the organism occurs "within a certain function of the psyche and is based on the mechanisms of maturation of the relevant physiological systems, because of teenagers is a transition between childhood and adulthood and it determines the social situation of its development" (Miasoid, 2001: 140).

Teenagers - a period of developing a system of stable views of the world around us, their place in it, as well as personal value self-determination. Teenagers is characterized by many features that cover all levels and aspects of mental development; among them are difficulties in communicating with adults, emotional instability, inadequate self-esteem, low self-control, etc., and the intimate experiences of a teenager are somehow related to finding themselves, knowing their abilities and capabilities, the desire to know how he is valued by the environment, with constant taking over the different roles of adults and the urgent need to form their own image of "I" (Dombrovska, 1995: 51).

The number of manifestations of the emancipation reaction (Latin emancipation - liberation) - the desire to get rid of parental care is growing. Feeling like a person equal to an 
adult, a teenager expects the appropriate attitude towards himself. The need for independence is transformed into a need for self-affirmation: the teenager embodies his sense of adulthood, often breaking the stability of relationships with people around him.

At this time there is an intensive formation of identity (from the Latin identical the same) - a characteristic of self-awareness associated with a sense of stability of his "I" (Miasoid, 2001: 149). Thus, I. Bech argues, "in adolescence there is a change in reference orientations, and the main system of relations is "of teenager - a significant of teenager", rather than "of teenager - a significant adult" (Bekh, 2003: 127).

\section{The psychology of aesthetic education and aesthetic activity of adolescents}

The content of aesthetic education of teenagers requires consideration of basic educational processes, in particular the education of spirituality, the dominant and crucial importance of which in the value development of adolescents requires personality-oriented education, which allows. A certain role is played by the "mechanism of biological adaptation, due to which the perception and emotions of the teenager are formed, aesthetic activity is realized, which interacts with mental processes" (Miasoid, 2001).

In the process of aesthetic activity, of teenagers receive certain information that ensures their diverse harmonious development, which, according to Kapustin, is "an acoustic accompaniment of everyday activities, an accompaniment to creativity, which is dynamically intertwined with various arts" (Kapustin, 1997). In this context, D. Feldshtein argued that teenagers a period of "growth of the individual in culture", in certain forms of society that exist in the form of ethics, science, art (Feldshtein, 1994). According to A. Petrovskyi, the criteria of self-esteem and the level of development of teenager's self-consciousness depend on the immediate social environment (Petrovskyi, 1987).

According to M. Zabrodskyi, adolescence is a "morning of life", which provides creative productivity, the probability of the greatest possible self-realization during later life (Zabrodskyi, 1998). An important point is the formation of self-esteem, intensive development of perception of oneself as a person of a certain sex with characteristic needs, motives, values and appropriate forms of behavior. All personality motives, in particular aesthetic ones, according to H. Remshmydt (Remshmydt, 1994), become more aware of A. Rean (Rean, 2016) and are experienced more fully and deeply.

Interacting in aesthetic activity there is a harmonious development of the semantic aspects of teenagers, which is the development of its spiritual, intellectual, moral and aesthetic aspects. "The current state of affairs in society puts the pupil in front of the need to define their life goals, to engage in joint activities, says I. Bekh, and only depends on him to what extent he perceives himself and others as unique individuals and to what extent he sees in them the means certain tasks" (Bekh, 2003a: 24).

In the aesthetic education of teenagers, the place and role of art from a psychological point of view, says G. Kostiuk, provides a clear understanding of its system of views, guidelines, ideas of the individual, regarding the conditions of their own life and life (Kostiuk, 2005).

It should be noted that the core of aesthetic education is perception, understanding of beauty - the basis of aesthetic culture, without which aesthetic feelings remain deaf to all that is beautiful. Therefore, we strive to ensure that the idea that beauty should be valued runs through all aspects of a child's human life - conversation and physical work, creativity, social activity, moral and aesthetic relations, friendship, love and take care. Stop in front of beauty - and beauty will blossom in front of you as well, "the teacher emphasized" (Sukhomlynskyi, 1977: 371). 
A. Petrovskyi ideas about dialogue on aesthetic education and artistic and pedagogical phenomena and situations, which influence the development of creative thinking of adolescents, are of scientific interest. Pedagogical interaction, communication in the form of aesthetically rich dialogue is presented as a relationship in the context of which the work of art is the subject and object of communication (Petrovskyi, 1987).

The images that are offered to teenagers to perform are born due to special emotional state, mental movements, concentrating on the inner "I". Among this structural system we single out the process of adolescent self-development as an expressive possibility of aesthetic orientations. According to V. Pakharenko, a teenager has a special psyche, he is characterized by emotional and symbolic thinking, much more than rational and conceptual, and he is more diverse and deeply perceives reality (Pakharenko, 1999).

This shows what teenagers is characterized by the development of value orientations - focus on certain values - standards of life, boys are focused on "good and faithful friends", "health", "active life", while girls - on "love", "interesting work", "happy family life" (Miasoid, 2001: 151). In view of this, value orientations expand the boundaries of the social situation of development, bring the adolescent to a higher level of relations with the world; he develops a willingness to self-determination.

Systematization of many approaches to understanding the psychological and pedagogical characteristics of adolescents as subjects of pedagogical interaction in aesthetic education has allowed us to characterize adolescence.

1. Teenagers' achievements are visible in the development of their reasoning and conclusions. They resort to reasoning, not only answering teachers' questions, but also out of their own need to make sure of the truth of certain judgments, to prove them, to present their opinion.

2. Interests in teenagers' often take the form of hobbies that literally consume the child's entire time, even to the detriment of school. The interests of children at this age are becoming more aware, the teenagers is increasingly guiding and supporting them, so, under conditions of successful interaction in aesthetic education, the development of artistic, aesthetic preferences, skills of perception is possible.

3. Teenagers' is marked by a rapid flow of emotions, sudden changes in emotional states, experiences, moods, translations from exaltation to incontinence, noise, from excessive mobility to calm, indifference. Sudden changes in the mood of teenagers caused by various factors: poor evaluation, frustration with a friend, inattention of adults to the interests and feelings of teenagers, tactless way of interfering in their emotional lives, allow fruitful communication and aesthetic activities in which teenagers relate to themselves and seek to show the best qualities of adult behavior.

4. Teenagers gradually develop the ability to observe the phenomena of the world, art in accordance with a specific purpose, to identify essential details, to clarify the relationships between them, which are taken into account by teachers in teaching and education, to identify essential features of subjects, to establish links between several objects, etc.

Interactive methods, in particular facilitated discussion, event technology, which allow to acquire significant changes not only in the motivational but also in the operational side of educational activities of teenagers, to increase the level of their abstraction and generalization, are important in communication, analysis and interpretation of works of art to form a system of direct and inverse logical operations, reasoning and conclusions, that become more conscious, reasonable, logically perfect, therefore, learning becomes more interesting, and the aesthetic activity of teenagers creative and productive.

Based on the analysis of many world scientific researches we will group the general, most essential for research psychological and pedagogical features of teenagers as subjects of pedagogical interaction in aesthetic education (Fig. 1). 


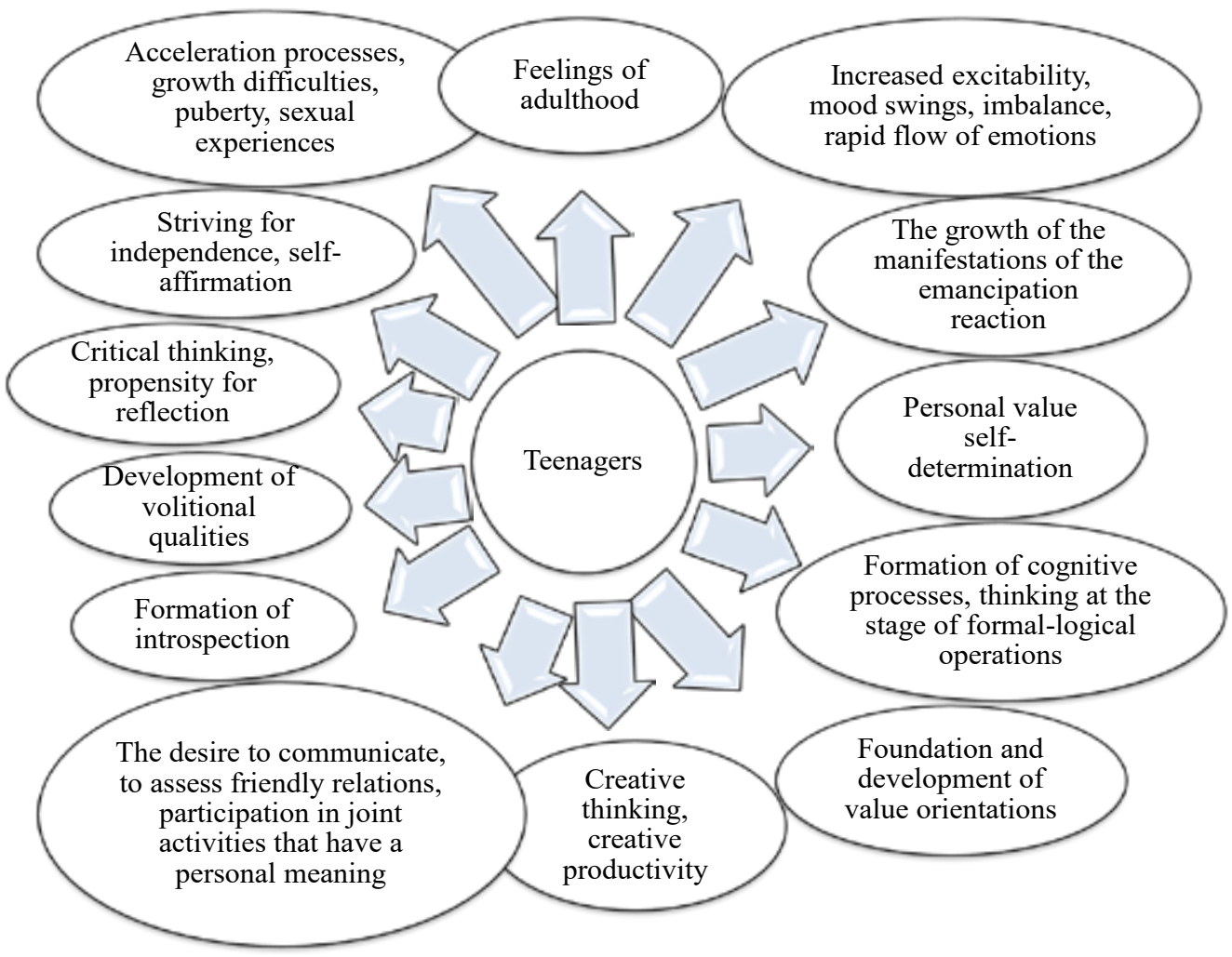

Fig. 1. The psychological and pedagogical features of teenagers as subjects of pedagogical interaction

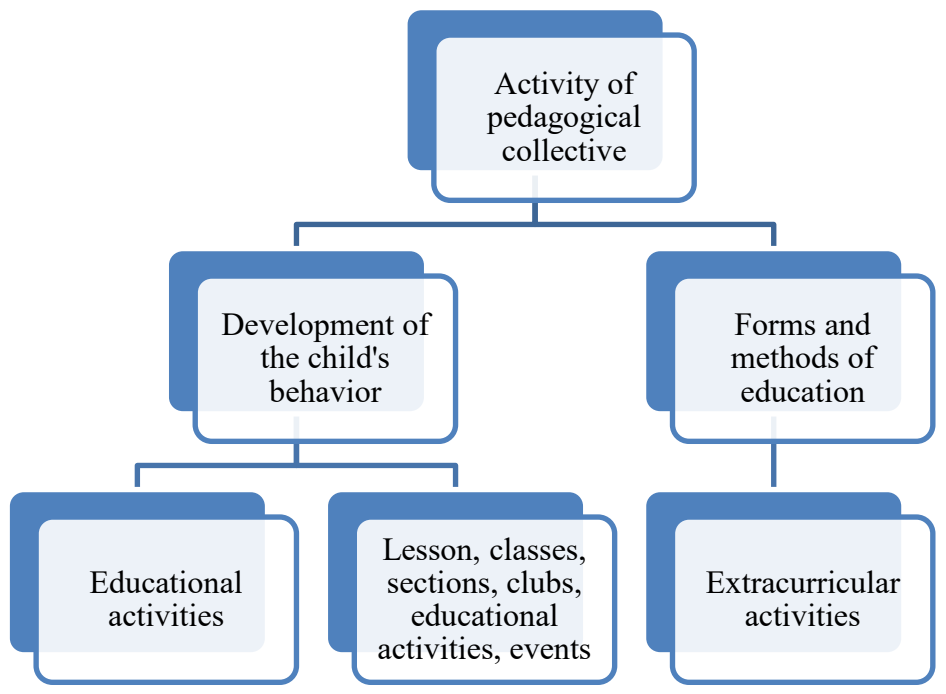

Fig. 2. Pedagogical factors of development of creative abilities of teenagers 
Based on the above psychological characteristics of teenagers, which are common and most typical for children of this age, we can draw conclusions about the psychological and pedagogical characteristics of adolescents as subjects of pedagogical interaction in aesthetic education.

Taking into account the identified scientific ideas, concepts, approaches that affect the effectiveness of aesthetic and educational impact on students, we have built a scheme of pedagogical factors (Fig. 2) that affect the development of creative abilities of teenagers and are important in aesthetic education of teenagers.

\section{Conclusions}

In the process of aesthetic activity and pedagogical interaction, teenagers express individual characteristics associated with the development of independent thinking, activity, creative approach to solving problems. By communicating and acting aesthetically, teenagers not only acquire knowledge on their own, use additional literature, dictionaries, computers, the Internet, but also learn to be creative, interact with each other, with art, with the world, etc, and enjoy creative aesthetic activities. Teenagers acquire aesthetic interests, tastes, preferences, achieve acme success.

\section{References}

Ananev, B. H. (1978). Chelovek kak predmet poznanyia. [Man as an object of knowledge]. Lenynhrad: LHU. [in Russia]

Bekh, I. D. (2003). Vykhovannia osobystosti. Osobystisno oriientovanyi pidkhid: teoretyko-tekhnolohichni zasady. [Personality training. Osobystisno oriientovanyi pidkhid: teoretyko- tekhnolohichni zasady]. Kn. 1. Kiev: Lybid. [in Ukrainian].

Bekh, I. D. (2003a). Vykhovannia osobystosti. Osobystisno oriientovanyi pidkhid: teoretyko-tekhnolohichni zasady. [Personality training. Osobystisno oriientovanyi pidkhid: teoretyko- tekhnolohichni zasady]. Kn. 2. Kiev: Lybid. [in Ukrainian].

Dombrovskaia, T. Y. (1995). Эstetycheskoe soznanye [Aesthetic consciousness] (fylosof. metod. analyz): (dys. d-ra. fylos. nauk: 09.00.08). B.-M. [in Russia]

Zabrodskyi, M. M. (1998). Vikova psykholohiia: [Age psychology]. Navchalnyi posibnyk. Kiev: MAUP. [in Ukrainian]

Kapustyn, Yu. A. (1987). Muzblkant-yspolnytel y publyka. [Musician performer and audience]. Moscow: Prosveshchenye. [in Russia]

Kostiuk, H. S. (2005). Navchalno-vykhovnyi protses i psykhichnyi rozvytok osobystosti. [Educational process and mental development of personality]. Kiev. Prokoliyenko. [in Ukrainian] Leontev, A. N. (1977). Deiatelnost, soznanye, lychnost. [Activity, consciousness, personality]. Moscow: Polytyzdat. [in Russia]

Miasoid, P. A. (2001). Zahalna psykholohiia: [General Psychology]. Navchalnyi posibnyk. Kiev: Vyshcha shkola. [in Ukrainian]

Neimark, M. S. Psykholohycheskyi analyz эmotsyonalnolkh reaktsyi shkolnykov na trudnosty $v$ rabote. [Psychological analysis of emotional reactions of schoolchildren to difficulties in work]. Vziato z: http://www.persev.ru/book/ms-neymark-psihologicheskiy-analiz-emocionalnyh-reakciy-shkolnikov-na-trudnosti-v-rabote 
Pakharenko, V. I. (1999). Nezbahnennyi apostol. [An incomprehensible apostle] Cherkasy: ChOIPPO. [in Ukrainian]

Rean, A. A. (2016). Psykholohyia lychnosty. [Personality psychology] St. Petersburg: Pyter. [in Russia]

Remshmydt, Kh. (1994). Podrostkovbli y yunosheskyi vozrast: Problema stanovlenyia lychnosty. [Adolescence and adolescence: The problem of personality formation]. Moscow. [in Russia] Sukhomlynskyi, V. O. (1977). Vybrani tvory: [Selected works] 5 t. Kiev: Rad. shkola. [in Ukrainian]

Terletska, L. H. (2013). Vikova psykholohiia i psykhodiahnostyka. [Age psychology and psychodiagnostics]. Kiev: Vydavnychyi Dim «Slovo». [in Ukrainian]

Tome, Kh. (1978). Teoretycheskye y эmpyrycheskye osnovbl psykholohyy razvytyia chelovecheskoi zhyzny. Pryntsypu razvytyia v psykholohyy. [Theoretical and empirical foundations of the psychology of human life development. Principles of development in psychology]. Moscow: Nauka. [in Russia]

Feldshtein, D. Y. (1994). Psykholohyia stanovlenyia lychnosty. [Psychology of personality formation]. Moscow: Mezhdunarodnaia pedahohycheskaia akademyia. [in Russia] 